\title{
OBJECTIVITY AND INDEPENDENCE ASSESSMENT OF AUDIT ACTIVITIES AND AUDITORS IN THE CONTEXT OF CORPORATE GOVERNANCE
}

\author{
Burcu İşgüden Kılıç*, Tufan Kuş **, Nevzat Çalış *** \\ * Bandırma Onyedi Eylül Üniversitesi İktisadi ve İdari Bilimler Fakültesi, **Ziraat Bankası, \\ ***Bandırma Onyedi Eylül Üniversitesi Bandırma Meslek Yüksekokulu \\ E-mail: burcuisguden@yahoo.com,tkus@ziraatbank.com.tr
}

Copyright (C) 2015 Burcu İşgüden Kılıç, Tufan Kuş, Nevzat Çalış. This is an open access article distributed under the Eurasian Academy of Sciences License, which permits unrestricted use, distribution, and reproduction in any medium, provided the original work is properly cited.

\begin{abstract}
It is known to influence corporate governance to provide of audit quality as well as auditors. Therefore, corporate governance principles are applied in conjunction with auditing standards, that may provide to access accurate and reliable information from financial statement, that are audited by objective and independent auditors. Audit activities carry some risks. Risks, that caused by objectivity and independence, are among them. Paid audit fee for external auditors by audited company and competitiveness of audit firms were called into questions about objectivity and independence of the auditors. In this context, the aim of our study was objectivity and independence evaluation of audit activities and auditors through the corporate governance practices.
\end{abstract}

Keywords: Corporate governance, Auditing, Auditor, Objectivity, Independence

JEL-Clasification: M42

\section{Kurumsal Yönetim Bağlamında Denetim Faaliyetlerinin ve Denetleyenlerin Tarafsızlık ve Bağımsızlıklarının Değerlendirilmesi}

\section{ÖZET}

Denetim kalitesinin sağlanmasında denetçilerin olduğu kadar kurumsal yönetim ilkelerine göre organize edilmiş bir şirket yönetiminin de etkili olduğu bilinmektedir. Bu nedenle denetim standartlarıyla birlikte uygulanan Kurumsal Yönetim İlkeleri toplumun ihtiyaç duyduğu doğru ve güvenilir bilgiye tarafsız ve bağımsız denetçilerce denetlenmiş mali tablolardan erimesini sağlayabilir. Denetim faaliyetleri bünyesinde bazı riskleri barındırmaktadır. Tarafsızlık ve bağımsızlık niteliklerinin sebep olduğu riskler bunların başında gelmektedir. Denetlenen şirket tarafından ödenen denetim ücretleri ve denetim firmaları arasındaki rekabet denetçinin tarafsızlığı ve bağımsızlığı hakkında soru işaretleri uyandırmaktadır. Bu bağlamda çalışmamızın amacı, kurumsal yönetim uygulamalarının bağımsız denetim faaliyetlerine ve denetleyenlere kazandırdığı tarafsızlık ve bağımsızlık özelliklerinin değerlendirilmesidir.

Anahtar Kelimeler: Kurumsal yönetim, Denetim, Denetçi, Tarafsızlık, Bağımsızlık 


\section{GíRISS}

Bir işletmenin iş ve ilişkilerini yöneten ve kontrol eden bir sistem olarak tanımlayabileceğimiz kurumsal yönetim kavramı, eşitlik, şeffaflık, hesap verebilirlik ve sorumluluk ilkeleri üzerine kurulmuştur. Bu ilkeler, işletme yönetiminin alacakları kararlarda kendi menfaatlerini değil, bütün paydaşların menfaatlerini ön plana almalarını zorunlu kılmakta ve bu bağlamda da işletme kültürüne "iyi yönetim" olgusunun yerleşmesini sağlamaktadır. Kurumsal Yönetim işletme yönetiminin kararlarının nasıl verildiğini belirleyen bir sistem olduğuna göre; bu sistemin en temel gerekliliklerinden biri de denetim ve denetimin bağımsızlığıdır.

Bağımsız denetim günümüzde önemi gittikçe artan ve kurumsal yönetimlerde güven ortamının sağlanması ve devam ettirilmesi için gerekli olan şeffaflığın sağlanmasında önemli bir role sahiptir. Bu nedenle bağımsız denetimin etkinliği ve uluslar arası standart ve etik kurallara uygun olarak gerçekleştirilmesi kurumsal yönetim açısından önem arz etmektedir. Fakat bağımsız denetim mesleğinde de artan rekabet meslek mensupları ve denetim firmalarını müşteri sayılarını koruma çabasına sürüklemiştir. Artan rekabet ayrıca meslek mensuplarının bağımsızlıkları üzerinde de bir tehdit oluşturmaya başlamıştır. $\mathrm{Bu}$ sebeplerden dolayı denetçilerin bağımsızlığı gündeme gelmiştir. Bu bağlamda denetimin bağımsızlığından bahsetmek için denetçilerin de bağımsız olmaları zorunlu hale gelmiştir.

Denetim birimlerinin tarafsızlığının ve bağımsızlığının korunmasında, yönetim ile denetim birimleri arasında şeffaf ilişkilerin kurulmuş olmasının önemli etkisi bulunmaktadır. Böylece denetçilerin hem denetim faaliyetleri sırasındaki sorumluluklarını layıkıyla yerine getirmeleri, hem de denetim raporlarını ilgili taraflara iletmeleri kolaylaşmaktadır. Denetim faaliyetleri, işletmenin değerini arttırmak, faaliyetlerinin verimliliğini yükseltmek ve denetim uygulamalarının kalitesini arttırmak amacıyla kurumsal yönetimin sağlamış olduğu kurallar dahilinde şirketin sahipliğini, yönetimi ve denetimi birbirinden ayırarak gerçekleştirilmelidir. Böyle bir denetim ortamı mali tabloların sunduğu bilgilerin doğruluğunu ve güvenilirliğini arttırmakta ve kamuoyunun hem denetim alanı hem de şirket yönetimi hakkında vardığ yargıları olumlu yönde etkilemektedir.

Denetimin kalitesi denetçinin kalitesi ile yakından ilişkilidir. Denetçiler öncelikle kamu yararını gözeterek tarafsızlıklarını ve bağımsızlıklarını korumalıdır. Küresel ölçekte meydana gelen pek çok yolsuzluk ve hile olayı, yüksek düzeydeki ticari baskıların, denetim ortamında sadece denetçilere güvenilemeyeceğini, denetçilerin çalışmalarından maksimum düzeyde yararlanmak için denetim komitelerinin gereken bağımsız ve tarafsız gözetimlerine ihtiyaç duyulduğunu göstermiştir. $\mathrm{Bu}$ amaçla, denetim faaliyetlerinin kapsamını, amacını, denetim ekibini, denetçilerin görev ve sorumluluklarını, yönetimin sorumluklarını ve denetim süreci ile ilgili gereken her türlü bilgiyi kapsayan kapsamlı denetim sözleşmelerine ve bu sözleşmelere uyulmaması durumunda karşılaşılacak yaptırımların belirlenmesine mutlaka ihtiyaç vardır.

\section{KURUMSAL YÖNETIMM}

Ekonomik hayatta yaşanan sürekli gelişme ve değişim, işletmeleri yoğun bir rekabet ve belirsizlik ortamında bırakmaktadır. Bu değişimler doğrultusunda işletmelerin mali tablolarına ilişkin güvenilir bilgiye olan ihtiyaç da artmaktadır. İşletme ile iş ilişkisinde olan karar alıcılar, işletmeye ilişkin bilgileri doğrudan kaynağından öğrenme olanağına sahip değildir. Bu nedenle karar alıcılar işletmeye ilişkin olarak başkaları tarafından hazırlanan bu bilgilerin 
güvenilirliğine inanmak durumundadırlar. Doğru ve güvenilir bilgiye olan ihtiyacın giderek artması bağımsız dış denetim faaliyetlerini de işletmeler için çok önemli bir gereksinim haline getirmiştir. Bilgilerin ve kararların objektif ve doğru olarak verilmesi, ancak belirli düzeydeki yöneticilerin işletme dışından olması durumunda mümkündür. Ayrıca globalleşme ile işletmelerin büyümeleri, çok uluslu şekle gelmeleri de yöneticilerin işlerini verimli biçimde yapmalarını zorlaştırmaktadır. Günümüzde, işletmelerin sürekliliğinin bir güvencesi olarak kabul edilen kurumsal yönetim, işletmelerin kötü yönetimlerine son vermek üzere ortaya atılmış bir anlayıştır (Alaylığlu, 2003: 11; Atamer, 2006: 9).

Türkçe literatürde, İngilizce "corporate governance" teriminin karşıllğı olarak kullanılan kurumsal yönetim kavramı, işletmelerin faaliyetlerinin taraflara karşı sorumluluklarının bilincinde olarak, işletmenin değerini ve verimliliğini arttıran, işletmenin ortaklarına, hissedarlarına ve çalışanlarına karşı önceden planladığı hedefleri tutturan, bunu yaparken söz konusu taraflarla yasalara uygun, etik değerler çerçevesinde çalışmalarda bulunan bir sistem olarak tanımlanmaktadır (Dinç ve Abdioğlu, 2009: 157-184).

Kurumsal yönetim; bireysel şirketler tarafindan yönetilen iç kontrol ve prosedürler sistemidir (Barrass 2007, 3). Başka bir tanıma göre ise; kurumsal yönetim, en geniş anlamda modern yaşamda insanların bir amaca ulaşmak için oluşturduğu herhangi bir kurumun yönetiminin düzenlenmesidir (TÜSİAD, 2002: 9). Aguilera (2005: 39)'e göre, kurumsal yönetim firmaların etkin bir şekilde yönetilmesini ve hissedarların ve çeşitli çıkar gruplarının değerinin maksimize edilmesini garanti etmek için mekanizmalar sağlayan bir sistem olarak nitelenebilir. Millstein (1998: 27), kurumsal yönetimin işletme yönetiminin kar elde edip pay sahiplerine dağıtma işlevinden ziyade, hissedarların, yöneticilerin ve diğer menfaat sahiplerinin de haklarını gözetildiği bir yönetim anlayışı olduğunu belirtmektedir. Başka bir tanıma göre ise; kurumsal yönetim, en geniş anlamda modern yaşamda insanların bir amaca ulaşmak için oluşturduğu herhangi bir kurumun yönetiminin düzenlenmesidir (TÜSİAD, 2002: 9).

Şirketlerde, yatırımcıların güvenini kazanmayı hedefleyen karar alma konumundaki çıkar sahiplerinin (stakeholders) yönetim işlevlerine bir şekilde katılımın sağlanması ve onların faaliyetler hakkında bilgilendirilmesini benimseyen, adil, şeffaf, hesap verebilir ve sorumluluk ilkeleri sahibi bir yönetim anlayışının varlığı önemlidir. Bu ilkeler sayesinde, işletmelerin verimli, rekabetçi ve etkin bir çalışma süreci yaşamaları mümkündür. Bu ilkeler evrensel olarak kabul edilmiş ilkelerdir. OECD tarafından benimsenen kurumsal yönetim ilkeleri; hissedar hakları, hissedarlara eşit davranılması, kurumsal yönetimde ortakların rolü, açıklık ve şeffaflık, olarak ifade edilmektedir (Türkiye Bankalar Birliği, 2006: 31-33). Kurumsal yönetim ilkeleri, genel olarak aşağıdaki gibi sıralanabilir (Sönmez ve Toksoy, 2011: 64-66):

Şeffaflık: Şirketin mali performansını gösteren doğru, gerekli ve geçerli verilerin ilgili tarafların bilgisine her şekilde açık olması olup, şeffaflık ilkesi ile ifade edilen, şirketin finansal performansı, kurumsal yönetimi, hissedarlık yapısı, iş ve faaliyetleri hakkında yeterli doğru bilginin açıklanmasıdır.

Hesap verebilirlik: Hesap verebilirlik, yönetime ilişkin kural ve sorumlulukların açık şekilde tanımlanması, şirket yönetimi ve hissedar menfaatlerinin yönetim kurulu tarafından gözetilmesini ifade etmektedir. Bu ilke ile ifade edilen, gerek yönetim ve gerekse ortak çıkarlarında denkliğin dikkate alınarak, yönetim süreçlerini ve eylemlerini gösteren ilkeler, normlar ve sorumlulukların belirtilmiş olmasıdır. 
Sosyal Sorumluluk: Sosyal Sorumluluk, şirket faaliyeti ve davranışlarının ilgili mevzuata, toplumsal etik değerlere uygunluğunun sağlanmasıdır.

Adil Olma: Azınlık ve yabancı hissedarlar dahil olmak üzere tüm ortakların hissedar haklarının korunması ve tedarikçilerle yapılan sözleşmelerin uygulanabilirliğinin sağlanması olarak ifade edilmektedir.

\subsection{Kurumsal Yönetimde Denetimin Yeri}

Kurumsal yönetimin eşitlik, şeffaflık, hesap verilebilirlik ve sorumluluk ilkeleri de, esasen iç ve dış denetimin sağlamayı hedeflediği kontrol mekanizmasını destekleyici niteliktedir. İç denetim ve bağımsız denetim koordineli bir şekilde uygulandığı takdirde, iç kontrol ile yatırımcılara, finansörlere ve diğer kullanıcılara güvenilir finansal rapor hazırlanmasını sağlanıp, şirketin hedeflerinin gerçekleştirilmesi için kaynakların etkin ve verimli olarak kullanıldığına dair operasyonel kontrollerin yapılması ve operasyonların ve mali tablonun kanun ve düzenlemelere uygun olup olmadığının denetimlerinin yapılması temel husus iken; bağımsız denetim ise işletmelerin halka açıklanacak yıllık finansal tablo ve diğer finansal bilgilerinin, finansal raporlama standartlarına ve genel kabul görmüş muhasebe ilkelerine uygunluğu ve doğruluğu hususunda, makul güvence sağlayacak yeterli ve uygun bağımsız denetim kanıtlarının elde edilmesi amacıyla tüm bağımsız denetim tekniklerinin uygulanarak, defter, kayıt ve belgelerin denetimin yapılması ve değerlendirilmesini dikkate almaktadır. Böylece etkin bir iç ve dış denetimin oluşturulması şirketlerde kurumsal yönetimin yerleştirilmesini sağlayan önemli bir araçtır (Göçen, 2010: 126).

Kurumsal yönetimin en önemli mekanizmalarından biri ihtiyatlı ve uyanık denetim komitesidir (Rezaee, 2002: 127). Denetim komitesi, finansal raporlama surecini izleyerek gerçeğe uygun finansal raporların üretilmesine olanak sağlamakta, muhtemel hata ve hilelere, yönetim başarısızlıklarına engel olmak suretiyle ortakların çıkarlarını korumakta, bağımsız dış denetim ve iç denetim çalışmalarını gözlemleyerek onlara yardımcı olmaktadır (Uyar, 2004: 110). Yönetim kurulunun finansal raporlama sureci ile ilgili gözetim sorumluluğunu yerine getirmesinde yardımcı olmak amacıyla kurulmuş olan denetim komiteleri, yönetimden bağımsız olarak, yönetim kuruluna bağlı olarak görev yapar (Demirbaş ve Uyar, 2006: 149_ 150). Denetim komitesi, yönetim kuruluna finansal bilgi akışını sağlayan bir kanal olarak hizmet ederek ve yönetim kurulu ile şirket yönetimi arasındaki bilgi asimetrilerini azaltarak finansal tablo hilelerinin oluşmasını azaltabilir (Rezaee, 2002: 127).

\subsection{Kurumsal Yönetimin Bağımsız Denetime Etkisi}

Bağımsız denetimin en önemli amaçlarından birisi piyasada güven ortamının sağlanmasıdır. $\mathrm{Bu}$ nedenle hazırlanan finansal tabloların denetçiler tarafından iyi analiz edilmesi gerekmektedir. Bunun yanında finansal tablolara güvenilirliğin sağlanması için finansal tablo hazırlama sürecinin de iyi işlemesi gerekmektedir. $\mathrm{Bu}$ sorumluluk tamamen müşteri firmanın sorumluluğundadır ve güçlü bir kurumsal yönetim sisteminin oluşturulması ile yerine getirilebilir(Goodwin, 2002: 196). Çünkü finansal raporlama süreci şirketin bütün birimlerinden etkilenmektedir. Doğal olarak finansal tabloların gerçeği yansıtıp yansıtmaması açısından sorumluluk finansal raporlama sürecini etkileyen bütün birimlerin olması gerekir ki bu da şirketin kurumsal yönetimidir (Ar1, 2008: 50). 
Finansal tabloların kalite, doğruluk, şeffaflık ve güvenirliğinin sağlanabilmesi tüm olarak kurumsal yönetim sorumluluğunun yerleştirilmesine bağlıdır. Kurumsal yönetim; finansal raporların doğruluğunu, kalitesini, şeffaflığını, güvenirliğini arttırıp; iç kontrol yapısının yeterlilik ve etkinliğinin sürekli gözetimini sağlayıp denetim fonksiyonlarının kalitesini arttırarak, şirketle ilgili tarafların çıkarlarının korunmasını sağlamaktadır (Rezaee, 2005: 289290).

Yapılan çalışmalar göstermektedir ki; kurumsal yönetimin zayıf olduğu ve bu nedenle gözetimin yetersiz olduğu yönetimlerde, finansal tablo hatalarının ortaya çıkma olasılığı yüksek bulunmaktadır (Hogan ve diğerleri, 2008: 235). İyi işleyen bir kurumsal yönetim sistemi, yönetim bildirimlerinin doğruluğunu sağlayarak denetim risklerini azaltmakta ve denetçiler kurumda var olan kurumsal yönetim mekanizmasının kalitesini değerlendirerek kendi çalışmalarını buna göre ayarlamaktadırlar (Pehlivanlı, 2010: 103).

\section{BAĞIMSIZ DENETIM FAALIYYTLERİ}

Bağımsız denetime olan güvenin artması için denetim faaliyetinin hem denetim standartlarına uygun olarak yapılması hem de bu faaliyetlerin ve sonuçlarının kamuoyuna duyurulması gerekmektedir. Denetim faaliyetleri sırasında denetçiler herhangi bir çıkar çatışmasına girmeksizin faaliyet göstermelidir.

\subsection{Bağımsız Denetimin Gerekliliği ve Dayanağ 1}

Bağımsız denetimin amacı şirketi, kurum ve kuruluşların sahip ve ortaklarına, alacaklıları ile kredi kuruluşlarına, işçi ve işveren kuruluşlarına, devletin ekonomik ve idari birimleri ile ayrıca vergi dairesine bunların mali tabloların da yer alan kayıtların gerçeğe uygun, doğru ve güvenilir olduğunu ortaya koymaktır (Ayranc1, 2010: 21).

İşletmelerin mali tablolarında yer alan bilgiler ve bu bilgilerdeki gelişmeler; sermayedarlar, yatırımcılar, yatırım yapmayı düşünenler, yöneticiler, işletme çalışanları, alacaklılar, sendikalar, meslek odaları, devlet, sosyal güvenlik kuruluşları, rakip işletmeler vb. tarafından kullanılır ve yakından izlenir (Dönmez, 2008: 9)

Yukarıda saydığımız kurum ve/veya şahıslar işletme ile ilgili karar alma sürecinde işletmenin finansal tablolarının önceden belirlenmiş ve ilgili tüm çevrelerce benimsenmiş belirli standartlara göre hazırlanıp hazırlanmadığına, başka bir ifadeyle; kendilerine sunulan mali bilgilerin güvenilirliğini temin edecek standartlarda olup olmadığına dikkat ederler. Çünkü belirli bir standardı olmayan muhasebe sistemine dayanılarak hazırlanan finansal tablolar, tabloyu yorumlayan kişiye göre farklı anlamlar ifade edebilir. Dolayısıyla tüm kesimlerce aynı dilin konuşulabilmesi ve güvenilirliğin sağlanabilmesi için tabloların genel kabul görmüş belirli standartlara uygun olarak hazırlanması gerekmektedir. Öyle ki, gelişen bilgi ve iletişim teknolojileri sayesinde artık küreselleşen dünyada ekonomik ilişkiler karmaşıklaşmış, uluslararası para ve mal hareketleri önündeki sınırlar büyük ölçüde kalkmış, çokuluslu işletmelerin faaliyet alanları alabildiğine genişlemiş ve küresel ekonomide aynı dilin konuşulması bir zorunluluk olmuştur. Büyük, halka açık işletmeler veya finans piyasasında faaliyet gösteren bankalar bu zorunluluğu çok daha fazla hissetmektedirler. Dolayısıyla söz konusu finansal bilgilerin güvenilir ve doğru olması, gerek ulusal gerekse uluslararası düzeyde 
genel kabul görmüş muhasebe ilkeleri ve standartlarına uygun bir hesap ve kayit sisteminin varlığı ile mümkündür. Bu doğrultuda muhasebe ilke ve standartlarının uygulanmakta olup olmadığını araştıracak, ilgili çevrelerin kullanımına sunacak bir sisteme ihtiyaç bulunmaktadır. Bu sistem "bağımsız denetim"dir. (Dönmez, 2008: 9) Bu sebeple bağımsız denetim önemli ve gereklidir.

\subsection{Bağımsız Denetimin Yararları}

Bağımsız denetimin sağladığı yararlar ana hatlarıyla birlikte işletmeler, ortaklar ve sermaye piyasaları açısından incelenmiştir.

Bağımsız denetimin denetlenen işletmeye sağladığı yararlar şu şekilde sayılabilir (Demirkan, 1998: 20; Dönmez, 2008: 11; Çelen, 2001: 30; Güler, 2006: 55; Oktay, 2003: 28):

- Bağımsız denetim finansal tabloların riskini azaltır, güvenilirliğini arttırır.

- Bağımsız denetim, denetimi yapılan işletmelerin muhasebe kayıtlarındaki hataların ortaya çıkarılmasını sağlar ve bu sayede gelir ve giderlerin tablolara doğru olarak yansitilmasina yardımci olur.

- Denetimi yapılan işletme yönetiminin ve çalışanlarının sahtekârlık yapma eğilimlerini azaltır.

- İşletmenin bağımsız denetimi sonucunda düzenlenecek olan raporlar, ilgililerin dikkatlerinin işletmenin zayıf noktalarına çekilmesini sağlar.

- Denetim sonunda verilen olumlu görüşler, işletmelerin daha kolay ve uygun şartlarda yabancı kaynak bulmasını sağlar.

- Yönetici kendi eksikliklerini, yanlışlarını veya finansal tablolarının uluslararası standartlara uymayan yönlerini objektif, dışarıdan bir gözle görme firsatı bulur.

- Bağımsız denetim, holding kuruluşları içinde işletme amaç ve politikalarına uyulduğu konusunda bilgi ve güvence verir.

- Bağımsız denetim işletmelerin uzun dönemde "güvenilir kurum imajı"nın oluşmasında saygı değer bir paya sahiptir. Bu imaj işletmeye artan pazar payı kazandırmakta ve işbirlikleri için tercih ve öncelik hakkı vermektedir.

Denetlenen işletmenin ortaklarına sağladığı yararların başında ortakların hakları gelir. Bağımsız denetim yapılmış işletmede ortakların hakları daha iyi korunmuş olur. Çünkü denetim faaliyeti tarafsı kişilerce gerçekleşir ve tarafsızca raporlanır. İşletmeyle ilgili her türlü yanlışlık, eksiklik açıkça ortaya çıkar (Demirel, 2007: 16).

Denetlenen işletme ile ilişkisi olan üçüncü kişilere ve sermaye-para piyasası'na sağladığı yararlar ise şu şekilde özetlenebilir (Çakmak, 2006: 27; Babayeva, 2006: 8):

- Mali tabloları, bağımsız bir dış denetçi tarafından denetlenmiş olan şirketler, gerek alım-satım ilişkisinde bulundukları şirketler açısından ve gerekse ilişkide bulunacakları para ve sermaye piyasası kuruluşları açısından yapılan değerlendirmelerde, mali tabloları bir bağımsız dış denetçi tarafindan denetlenmemiş olan şirketlere kıyasla önemli avantajlar sağlamaktadırlar. Çünkü bağımsız dış denetimden geçmiş ve mali tabloları tasdik edilmiş bir şirket denetim raporunda belirtilen şartlar ve kayıtlar çerçevesinde güvenilir ve tercih edilir bir şirkettir.

- Sermaye Piyasası; işletmelerin uzun vadeli veya devamlı fon ihtiyaçlarının giderilmesi araçlarını oluşturan menkul kıymetlerin arz ve taleplerinin karşılaştı̆ı 
ve bu arz ve taleplerin karşılaşmasını sağlayan kurumları içeren piyasa olarak tanımlanabilmektedir.

- Piyasada fon arz eden yatırımcılar gerçek ve tüzel kişiliğe sahip olup, genellikle kişisel tasarrufları, işletme tasarrufları ve finansal kurumlardır. Fon talep edenler ise işletme kişiler, şirketler ve finansal kurumlardır. Fon arz edenler kendilerine gelir sağlamaktadırlar. Fon talep edenler ise, kendilerine gereken fon sağlamış olurlar. Küçük tasarruflar büyük tasarruflara dönüşmekte bu da sermaye piyasasının ülke ekonomisindeki önemini ortaya koymaktadır.

- Ekonominin büyümesi ve gelişmesini etkileyen faktörlerden biri de etkili ve güvenilir bir Sermaye Piyasasının kurulmasıdır. Sermaye Piyasasının güvenilirliliğinin sağlanması bağımsız denetim uygulamaları ile gerçekleştirilir.

\section{DENETLEYENLERİN TARAFSIZLIĞI VE BAĞIMSIZLIĞI}

Finansal tablolara güvenilirliğin sağlanması için finansal tablo hazırlama sürecinin iyi işlemesi gerekmektedir. Bu sorumluluk tamamen müşteri firmanın sorumluluğundadır ve güçlü bir kurumsal yönetim sisteminin oluşturulması ile yerine getirilebilir (Acar ve diğerleri, 2011: 278). Bağımsız denetim ise kurumsal yönetimin önemli bir bileşenidir. İşletmeler kurumsal yönetim yapısını tamamlamak ve desteklemek için yüksek kaliteli denetim hizmeti talep ederler (Karaibrahimoğlu, 2013: 273). Denetimin kalitesi ise denetçinin kalitesi ile yakından ilişkilidir. $\mathrm{Bu}$ ilişkide denetçinin tarafsızlık ve bağımsızlık özellikleri önemli bir etkiye sahiptir.

Tarafsızlık, denetçilerin görevlerini, iş sonucunda çıkan ürüne gerçekten ve dürüst bir şekilde inanacakları ve bu ürünün kalitesinden taviz vermeyecekleri şekilde yapmalarını sağlayan bir zihinsel tutumdur. Bağımsızlık ise tarafsızlık ve tarafsızlık görüntüsünü bozacak şartların dişında olmaktır (Institute of Internal Auditors, 2008: 35-38). Denetçiler inceledikleri süreç ve faaliyet ile ilgili bilgiyi toplarken, değerlendirirken ve raporlarken mesleki tarafsılık sergiler ve hem kendilerinin hem de başkalarının menfaatlerinden etkilenmezler. Mesleki yargıları zayıflatacak durumlardan kaçınır ve açıklanmadığı takdirde faaliyetlerin raporlanmasını bozacak tüm önemli bulguları açıklarlar. Bağımsızlık ve tarafsızlık kavramlarını, birbirinden kesin çizgilerle ayıramayabiliriz. Bu kavramlarla ilgili yapılan düzenlemelerde kavramların birlikte ele alındığı ve birbirini tamamlayan kavramlar olarak düzenlendiği görülmektedir (Otlu, 2001).

IFAC Meslek Ahlakı Kurallarına göre bağımsızlığı tehdit eden haller arasında kişisel menfaat tehdidi, kendi kendini denetleme tehdidi, savunma tehdidi, samimiyet veya güven tehdidi, yıldırma tehdidi sayılabilir. Bunların yanı sıra denetim ücretinin denetim sonuçları ile ilgili şartlara bağlanmış olması, denetimin kalitesine dair belirsizlikler, denetim kuruluşu tarafından denetlenen işletmeye sunulan denetim dişı diğer hizmetler bağımsızlığın korunması açısından dikkate alınmalıdır. Özellikle denetim ücreti, denetimin bağımsızlığını, tarafsızlığını ve kalitesini sağlayacak şekilde belirlenmelidir (Uzay: 2004: 437).

\subsection{Bağımsız Denetçinin Tarafsızlığının ve Bağımsızlığının Kurumsal Yönetim Açısından Değerlendirilmesi}

Denetçilerin bağımsız ve tarafsız olmaları denetimi etkileyen temel faktörlerdedir. Bağımsız ve tarafsız olabilmek adına katkı sağlaması istenen pek çok uygulama olmakla birlikte bunların başında ücret konusu gelmektedir. Denetim hizmeti karşılığı olarak alınan ücretin uygun 
düzeyde olmamasının denetimin kalitesi üzerinde etkisi mevcuttur. Denetim dişı hizmet gelirlerinin yüksek olmasından ziyade, denetim gelirleri içerisindeki payının yüksek olmasının denetim firması ve denetçinin bağımsızlığını zedelediği dolayısıyla denetimin kalitesini etkilediği belirtilmektedir. Çünkü denetim dışı hizmet gelirlerinin, toplam gelir içerisinde geniş bir büyüklüğe sahip olması, finansal olarak denetçinin müşteriye bağlı olmasına sebep olabilmektedir. Enron, World Com gibi skandalların yaşanmasından sonra Sarbanes Oxley Yasası ile denetim firmalarının denetim hizmeti verdiği müşterisine aynı zamanda denetim dışı hizmet vermesi yasaklanmıştır. Denetim firmalarının belli müşterilerinden elde ettikleri gelir miktarının toplam gelirleri içerisinde çok yüksek bir paya sahip olmasının da, müşteriye olan finansal bağımlılığı arttırması nedeniyle bağımsızlığı zedeleyebileceği düşünülmektedir (Acar ve diğerleri, 2011: 278). Denetim firması seçiminde önemli bir faktör olan denetim ücreti devre dışı tutularak bir açıklama yapılır ise; kurumsal yönetim anlayışı ile yönetilen isletmeler daima kaliteli bağımsız denetim hizmeti sunan firmaları tercih edeceklerdir (Oktay, 2013: 49).

Uluslararası Denetim Standartlarına (UDS) göre denetçiler görevlerinin her aşamasında bağımsız düşünme mantığı içinde olmalıdır UDS 220 Finansal Tabloların Denetiminde Kalite Kontrol standard 1 geçmiş finansal bilgilerin denetimine yönelik kalite kontrol hakkında denetçilerin belirli sorumluluklarına yol gösterirken etik gereklilikler olarak tarafsızlık ve bağımsızlık konularına ayrı ayrı değinmiştir. İlgili standartta denetim kalitesi, denetlenen işletmenini finansal tablolarına ilişkin uygun görüşü sunmak ve bu görüşü gerekli kanıtlarla ve tarafsız yargılarla desteklemek olarak açıklanmıştır. Denetçiler bağımsız, güvenilir, yeterli ve uygun denetim kanıtları ile desteklenmiş bir denetim raporu hazırladıklarında kaliteli bir denetim hizmeti vermiş olacaklardır (Cömert ve diğerleri, 2013: 34-35).

2002 yılında ABD'de patlak veren Enron krizinden sonra, uluslar arası düzenleyici kurumların denetime yönelik yaptığı yeni düzenlemeler ışı̆̆ında, 8. Yönerge yenilenmiştir. 17 Mayıs 2006 tarihinde, 43 Numaralı Direktif ile yapılan bu değişiklikler arasında "Mesleki etik, bağımsızlık, tarafsızlık ve mesleki gizlilik” başlığı da yer almıştır (Esendemirli, 2013: 98).

2010 yılında EISBA'nın yayınladığı etik kurallardaki en önemli değişiklik 290 BağımsızlıkDenetim ve İnceleme Sözleşmeleri ve 291 Bağımsızlık-Diğer Güvence Sözleşmeleri kodlu etik kodlardır. Bu kodlar bağımsız denetçilerin uymak zorunda olduğu etik kurallar setidir. 290 kodlu etik kuralda bağımsızlık kavramına yaklaşım; denetim sözleşmeleri kamu yararına yapılır ve denetim ekibinin üyelerinin, denetim firmasının ve işletmelerin bağımsız olması ilk koşuldur. $\mathrm{Bu} 290$ kodlu etik kural ile bağımsızlı̆̆ tehdit eden unsurları belirleme, değerlendirme ve ortadan kaldırma amacıyla denetim ekibinin ve denetim firmalarının gereksinim duyduğu kavramsal çerçeve belirlenmiştir. 290 kodlu etik kurallar bağımsızlığın yanı sıra kurumsallaşmanın önemini de vurgulamaktadır. Kurumsallaşmanın kalite kontrol standartlarının belirlenmesinde ve etik kurallarla uyumun sağlanmasında önemli bir rol oynadığ1 savunulmaktadır. 291 kodlu etik kurallarda ise denetim ve inceleme sözleşmesi olmayan güvence sözleşmeleri için bağımsızlık şartları incelenmektedir. Güvence ekiplerinin veya firmalarının güvence hizmeti talep eden müşterilerden bağımsız olmaları gerekir (Cömert ve diğerleri, 2013: 575-581).

4.2. İç Denetçinin Tarafsızlığının ve Bağımsızlığının Kurumsal Yönetim Açısından Değerlendirilmesi 
İşletmenin kurumsal yönetim sürecine destek olmak amacıyla iç denetçilerin dikkate alması gereken konular arasinda;

- Kurumun kanunlara ve düzenlemelere uyumuna, etik ve menfaat çatışmalarına ilişkin politikalarını ve suiistimal iddialarının zamanında ve derinlemesine araştırılması ve takibiyle ilgili politikalarını gözden geçirmek

- Kurumsal risk ve yönetim riski taşıyan derdest davaları veya idari soruşturmaları ve takipleri gözden geçirmek

- Personelin menfaat çatışmaları, usulsüzlük ve suiistimalleri hakkında ve kurumun ilgili etik prosedür ve raporlama mekanizmalarının diğer sonuçları hakkında bilgi vermek

yer almaktadır (Institute of Internal Auditors, 2008: 351).

Şirketlerde iç denetim sayesinde bilgilerin güvenilirliğinin sağlanmaya çalışılması kafalarda bazı soru işaretlerinin oluşmasına neden olmaktadır. İç denetçilerin bir ücret karşıllı̆ı denetim yaptıkları şirkette tam zamanlı çalışıyor olmaları bilgilere kuşkuyla yaklaşılmasına sebep olmaktadır. Bu durumda finansal bilgilerin güvenilirliğinin ve doğruluğunun şirket ile menfaat ilişkisi olmayan, bağımsız bir denetçi tarafından tasdik edilmesi gerekmektedir.

İç denetçilerin bağımsızlığı ve tarafsızlığını ne yönde etkileyeceğini tespit etmek amacıyla denetim hizmetlerinin dışarıdan satın alınması konusunda literatürde bazı araştırmalar yapılmıştır. Örneğin; Ahlawat ve Lowe (2004) tarafından yapılan çalışmada, iç denetimin dış kaynaklardan satın alınması ve içeriden sağlanması durumlarında denetçinin tarafsızlığının etkilenip etkilenmediği araştırılmış ve elde edilen sonuçlara göre iç denetim hizmetlerinin diş kaynaklardan sağlanması durumunda denetçinin tarafsızlığının daha fazla olacağı sonucuna varılmıştır.

İç Denetçiler Enstitüsü’nün hazırladığı 1120 no'lu Nitelik Standardına göre “iç denetçiler, tarafsız ve önyargısız olmalı ve çıkar çatışmalarından kaçınmalıdır" denilmektedir. 2001 yılında İç Denetçiler Enstitüsü’nün araştırma kuruluşu tarafından "Bağımsızlık ve Tarafsızlık: İç Denetçiler için bir Çerçeve" (Independence and Objectivity: A Framework for Internal Auditors) başlıklı bir çalışma yayımlanmıştır. Bu çalışmada iç denetçilerin tarafsızlığına yönelik tehdit oluşturabilecek yedi alan üzerinde durulmuştur. Bunlar: öz değerlendirme, sosyal baskı, ekonomik çıkar, kişisel ilişki-samimiyet ve kültürel, ırksal, cinsiyet ve zihinsel temelli önyargılardır. Buna ilaveten literatürdeki bazı çalışmaların sonuçları incelendiğinde yönetim baskısının, mesleki atamalarının, yönetime danışmanlıklarının, dış kaynak kullanımının, yönetim ve denetim komitesine yakınlıklarının iç denetçilerin tarafsızlıkları üzerinde büyük öneme sahip olduğu görülmüştür (Kızılboğa, 2013: 115).

IIA'nın Etik Kuralları'nda iç denetim mesleği ve uygulamasıyla ilgili ilkeler ve iç denetçilerden beklenen davranış tarzını tanımlayan davranış kuralları iç denetçilerin etik davranışları konusunda kılavuzluk sağlamaktadır. İlkeler içinde yer alan tarafsızlık ilkesi ile iç denetçilerin inceledikleri süreçte bilgiyi toplarken, değerlendirirken ve raporlarken üst düzeyde mesleki tarafsızlığa ihtiyacı olduğu vurgulanmaktadır. İç denetçi kendisinin ve diğerlerinin menfaatlerinden etkilenmemelidir. Davranış kuralları açısından bakıldığında tarafsızlık başlı̆̆ altında iç denetçilerin tarafsızlığı bozacak ilişkilerden kaçınması, mesleki yargıyı zayıflatabilecek durumlardan kaçınması ve faaliyetlerin raporlanmasını bozacak tüm önemli bulguları açıklaması gerektiği vurgulanmaktadır (Institute of Internal Auditors, 2008: 12-13). 
4.3. Denetim Komitesinin Tarafsızlığının ve Bağımsızlığının Kurumsal Yönetim Açısından Değerlendirilmesi

Denetim Komitesi kurumsal yönetim ilkeleri çerçevesinde şirketlerin finansal raporlama süreci, finansal raporlama ile ilgili iç kontrol sistemi, denetim süreci, yasal düzenlemeler ve etik kurallara uygunluk kontrollerine ilişkin gözetim sorumluluğunun yerine getirilmesini sağlamakta ve yönetim kuruluna destek olmaktadır (Kurt ve Akyüz, 2009: 233). Denetimden sorumlu komite vasıtasıyla şirketin finansal ve operasyonel faaliyetleri gözlemlenebilir ve tavsiyeler paylaşılabilir. Ayrıca işletme performansını belirlemek için kurumsal yönetim ilkelerine uyumlu olarak her türlü iç ve dış denetimin yapılmasını sağlanabilir.

\subsubsection{Denetim Komitelerinin Etkinliğini Etkileyen Unsurlar}

İşletmelerde etkin bir kurumsal yönetim yapısı oluşturmanın yolu etkin bir denetim komitesinden geçmektedir. Bu kurumsal sorumluluğun şirket içinde yerleşebilmesi için finansal raporlama ve iç kontrol sistemin etkinliğinin arttırması gerekmektedir Ayrıca kurumsal yönetim ilkelerinden olan işletmelerde şeffaflığın sağlanması ve kamuoyunu bilgilendirme kavramı (hesap verebilirlik) denetim komitelerinin asli görevlerindendir (Çatıkkaş ve diğerleri, 2012: 21).

Wild (1996) tarafından denetim komiteleri üzerine yapılan bir araştırmada, denetim komitelerinin işletmelerin muhasebe kalitesini arttırıp arttırmadığı incelenmiştir. Elde edilen bulgulara göre denetim komitelerinin işletmelerin muhasebe kalitesini arttırdığ 1 ve \% 20'den daha fazla bir oranda işletmelerin karlılığına katkı sağladığı belirlenmiştir.

4.3.2.Denetim Komitesinin Etkileşimleri: Bağımsız Denetçi, İç Denetçi, Yönetim Kurulu, Yönetim

Kurumsal yönetim, işletmedeki tüm birimlerin rollerini belirler ve bunlar arasında bir denge ve kontrol mekanizması kurar. Uluslararası İç Denetçiler Enstitüsü (IIA) sağlam bir yönetimin, etkin bir kurumsal yönetim sisteminin 4 unsuruna bağlı olduğunu savunmaktadır. Bunlar; bă̆ımsız denetçi, iç denetçi, yönetim kurulu, yönetimdir.

Denetim Komitesi-Bă̆ımsız Denetçi Etkileșimi:

Denetim komitesinin görev ve sorumlulukları yönetim kurulunun gözetim fonksiyonundan gelmektedir. Yapılan bu gözetimin en önemli amaçlarından birisi, finansal hileleri önlemek için faaliyet gösteren bağımsız denetçinin bağımsızlı̆̆ını ve tarafsızlığını sağlamaktır (Çatıkkaş ve diğerleri, 2012: 40). İşletmede hissedarların bir temsilcisi olarak faaliyet gösteren denetim komiteleri bağımsız denetçinin bağımsızlığını sağlama görevini üstlenmiştir. Komite denetim dışı hizmetlerde bağımsız denetçiden yararlanılıp yararlanılmadığını inceleyerek, denetçiişletme ilişkisini tartışarak ve takip ederek bağımsız denetçinin bağımsız hareket ettiğini garanti altına almalıdır. Denetim komitesi ile bağımsız denetim kuruluşu arasındaki ilişkinin başlangıcı, bağımsız denetim sözleşmesinin imzalanmasına dayanmaktadır (Çatıkkaş ve diğerleri, 2012: 47-48-49).

Denetim komitesi-İç Denetçi Etkileșimi:

Denetim komitesinin bir işletmenin faaliyetlerini tam olarak anlayabilmesi için iç denetçilerin işlerini değerlendirmesi gerekir. Uluslararası İç Denetçiler Enstitüsü (IIA) denetim komiteleri ve iç denetçilerin amaçlarının birbirine bağlı olduğunu kabul eder. Denetim komitesi ile iç 
denetçiler arasında esas olarak "iç denetim yöneticisi” aracılığıyla etkin bir iletişim kurmak için 3 önemli alan vardır (Institute of Internal Auditors, 2008: 210):

- Denetim komitesine, sorumluluklarını yerine getirebilmesi için yönetmelik, faaliyet ve süreçlerinin uygun olmasını sağlamaya yardımcı olmak,

- İç denetim yönetmeliği, rolü ve faaliyetlerinin anlaşılmasını ve bunların denetim komitesinin ve yönetim kurulunun ihtiyaçlarına cevap verecek şekilde olmasını sağlamak,

- Denetim komitesi ve başkanıyla etkin bir iletişim sürdürmek.

İç denetim fonksiyonun, finansal raporlama, kurumsallık ve kontrolle ilgili sorumluluklarını etkin bir şekilde yerine getirebilmesi, denetim komitesi ile bir raporlama ilişkisini gerektirir. Böyle bir ilişkinin var oluşu üst yönetim kaynaklı hilelerde, kötü yönetim gibi durumlarda denetçiye müracaat edebileceği bir merci kazandırmaktadır (Yılanc1, 2003: 29).

Denetim Komitesi-Yönetim/Yönetim Kurulu Etkileșimi:

WorldCom ve Enron skandallarında yüksek düzeydeki ticari baskılar dikkate alındığında yönetim kurulunun ve hissedarların sadece bağımsız denetçilerin bakış açılarına güvenemeyecekleri görülmüştür. İşletme faaliyetleri ile ilgili önemli tespitler; usulsüzlük ve yolsuzluklar, yasa dışı fiiller, hatalar, verimsizlik, israf, etkisizlik, çıkar çatışmaları ve kontrol zayıflıkları gibi durumlar iç denetim birimlerinde belirlenebilir. Bu gibi durumların varlığ mutlaka yönetime bildirilmelidir. Yönetimin göre ve sorumluluğu iç denetim biriminin yaptığ tespitleri dikkate alarak gereken tedbirleri almaktır. Yönetimin alacağı tüm tedbirler ayrıca hem denetim komitesine hem de yönetim kuruluna bildirilmelidir (Institute of Internal Auditors, 2008: 208).

\section{SONUÇ VE ÖNERILER}

Kurumsal yönetim ve denetim faaliyetlerinin birlikteliği, her iki mekanizmanın da işlerliğini arttırmaktadır. Kurumsal yönetim ilkelerinin uygulanması, denetim faaliyetlerinin tarafsız ve bağımsız bir şekilde yerine getirilmesi ile mümkün olabilecektir. Denetim standartları ve etik kurallar vasitasıyla yerine getirilen denetim faaliyetleri kurumsal yönetim ilkeleri ile desteklenmiş olacaktır.

Finansal bilginin kalitesinin ve güvenilirliğinin arttırılmasında ve bilgi kullanıcılarına doğruluğu ve dürüstlüğü onaylanmış bilgilerin sunulmasında denetim standartları doğrultusunda gerçekleştirilen denetim faaliyetlerinin etkili olduğu bilinmektedir. Bu açıdan denetim faaliyetleri sırasında denetçinin tarafsızlığı ve bağımsızlığı finansal raporlama sürecindeki problemlerin tespit edilip bilgi kullanıcılarına duyurulmasında en önemli etkenlerdendir. Böylece kurumsal yönetim ilkelerinden hesap verebilirlik ve şeffaflık ilkelerinin uygulanma derecesi de yükselmiş olur. Denetim sürecinde denetim komitesinin varlığı ise kurumsal yönetim yapısının oluşturulması ve denetçi ile işletme arasındaki bilgi-alış verişinin tarafsız ve bağımsız bir şekilde gerçekleşmesi açısından katkı sağlamaktadır. Ayrıca denetim komitesinin varlığ1 ve uzmanlığ noktasında da kılavuzluk sağlayabilir.

Denetçinin tarafsızlığı ve bağımsızlığı her şeyden önce kendi sorumluğundadır. Denetim faaliyetlerinin denetim standartları doğrultusunda gerçekleştirilmesi ile denetimin genel amaçları ve denetim sürecinde denetçilerin sorumlulukları doğrudan belirlenmiş olacaktır. $\mathrm{Bu}$ 
sürece meslek etiği ile ilgili kuralların entegre edilmesi, denetim faaliyetlerinin kalitesini arttırmakla birlikte esasen denetçinin tarafsızlık ve bağımsızlık niteliklerinin güçlendirilmesini sağlayacaktır. Ayrıca meslek etiği ile ilgili kuralların yarattığı denetim süreci, bu sürecin kalitesi ve denetleyenlerin niteliklerindeki yükseliş kurumsal yönetim ilkelerinin güvence altına alınmasını sağlayacaktır.

\section{REFERENCES}

- Acar, D., S. Senal ve H. Usul. (2011). "Bağımsız Denetim Kalitesi: Denetim Firmaları Üzerine Bir Araştırma", Sosyal ve Ekonomik Araştırmalar Dergisi, Cilt:16, Yıl:11, Sayı:22: 273-307.

- Aguilera, R. V. (2005). "Corporate Governance and Director Accountability: An Institutional Comparative Perspective", British Journal of Management,16(1): 39-53.

- Ahlawat, S. S. ve D. J. Lowe. 2004. "An Examination of Internal Auditor Objectivity: In House Versus Outsourcing”, Auditing: A Journal of Practice \& Theory, 23 (2): 147-158.

- Alayoğlu, N. (2003). Aile şirketlerinde Yönetim ve Kurumsallaşma. İstanbul: MÜSİAD Yayınları.

- Ar1, M. (2008). “Kurumsal Yönetim ve Finansal Raporlamanın Güvenilirliği”, Osmangazi Üniversitesi İİBF Dergisi, 3(2). 43-68.

- Atamer, M. (2006). Halka Açık Anonim Şirketlerde Kurumsal Yönetim ve Doğrudan Yabancı Yatırımlar Açısından Değerlendirilmesi (Uzmanlık Tezi), Ankara: TC Hazine Müsteşarlığı.

- Ayrancı, K. (2010). Türkiye'de Bağımsız Denetim ve Bir İşletme Uygulaması, Sakarya Üniversitesi Sosyal Bilimler Enstitüsü, Yayınlanmamış Yüksek Lisans Tezi, Sakarya.

- Babayeva, L. (2006). Türkiye ve Azerbaycan Bağımsız Denetim Sistemlerinin Karşılaştırılması, Sakarya Üniversitesi Sosyal Bilimler Enstitüsü, Yayınlanmamış Yüksek Lisans Tezi, Sakarya.

- Barrass, J. (2007). Corporate Governance and Ethics: Why They Matter. Head, Europe, Middle East, Africa, CFA Centre for Financial Market Integrity. Bank of Garanti Istanbul 17 March 2007 Presentation.

- Cömert, N., S. K. Selimoğlu, Ş. Uzay ve S. Uyar. (2013). Uluslararası Denetim Standartları Kapsamında Bağımsız Denetim, Sakarya: Sakarya Üniversitesi Sürekli Eğitim Uygulama ve Araştırma Merkezi.

- Çakmak, N. (2006). İşletmelerde İç ve Dış (Bağımsız) Denetim Faaliyetleri Ve Bankalarda Uygulanışı, Kocaeli Üniversitesi Sosyal Bilimler Enstitüsü, Yayınlanmamış Yüksek Lisans Tezi, Kocaeli.

- Çatıkkaş, Ö., M. Okur ve İ. Balkan. (2012). Bankalarda Denetim Komitesi Uygulaması, İstanbul: Türkiye Bankalar Birliği Yayın No: 287.

- Çelen, E. (2001). "Bağımsız Denetimin Önemi, Yararları ve Kamuyu Aydınlatma İlkesi”, Mali Çözüm Dergisi, 55.

- Demirbaş, M., ve S. Uyar. (2006). Kurumsal Yönetim İlkeleri ve Denetim Komitesi, İstanbul: Güncel Yayıncilık.

- Demirel, A. (2007) Bağımsız Denetimde İşletme İç Kontrol Yapısının İncelenmesi ve Bir Uygulama Örneği, Marmara Üniversitesi Sosyal Bilimler Enstitüsü, Yayınlanmamış Yüksek Lisans Tezi, İstanbul.

- Demirkan, Ş. (1988) Türkiye'de Denetimin Vergi Gelirlerinin Artırılmasında Etkenliği, Dokuz Eylül Üniversitesi Sosyal Bilimler Enstitüsü, Yayınlanmamış Doktora Tezi, İzmir. 
- Dinç, E. ve H. Abdioğlu. 2009. "İşletmelerde Kurumsal Yönetim Anlayışı ve Muhasebe Bilgi Sistemi İlişkisi: İMKB-100 Şirketleri Üzerine Ampirik Bir Araştırma”, Balıkesir Üniversitesi Sosyal Bilimler Enstitüsü Dergisi, 12 (21): 157-184.

- Dönmez, A (2008) Bağımsız Denetim Sürecinde Kullanılan Analitik İnceleme Prosedürlerinin Denetim Standartları Açısından Değerlendirilmesi Ve Türkiye'de SPK'dan Yetki Almış Denetim Firmaları Üzerine Bir Araştırma, Akdeniz Üniversitesi Sosyal Bilimler Enstitüsü, Yayımlanmamış Doktora Tezi, Antalya.

- Ergin, H. 2007. Denetim, Kütahya: Dumlupınar Üniversitesi Yayınları.

- Esendemirli, E. (2013). "Bağımsız Denetimde Kalite Kontrol ve YMM'lere Yönelik Bir Uygulama”, MÖDAV Muhasebe Bilim Dünyası Dergisi, 15 (2): 91-122.

- Goodwin, J., and J. L. Seow. (2002). “The Influence of Corporate Governance Mechanisms On The Quality Of Financial Reporting And Auditing: Perceptions Of Auditors And Directors in Singapore", Accounting \& Finance, 42(3): 195-223.

- Göçen, C. A. 2010. "Kurumsal Yönetim, İç Kontrol ve Bağımsız Denetim: Parmalat Vakası", Mali Çözüm Dergisi, 97: 107-129.

- Güler E. (2006). Bağımsız Dış Denetim Süreci-Kurumsal Sosyal Sorumluluk İlişkisiBankacılık Sektörü Uygulaması, Marmara Üniversitesi., Bankacılık ve Sigortacılık Enstitüsü, Yayınlanmamış Doktora Tezi, İstanbul.

- Hogan, C. E., Z. Rezaee, R. A.Riley Jr And U. K. Velury. (2008). "Financial Statement Fraud: Insights From The Academic Literature", Auditing: A Journal Of Practice \& Theory, 27(2): 231-252.

- İMKB. (2005). “İMKB Kurumsal Yönetim Endeksi Temel Kuralları”, vww.imkb.gov.tr, (Erişim tarihi: 11.10.2014).

- Karaibrahimoğlu, Y. Z. (2013). "Is Corporate Governance A Determinant of Auditor Choice?-Evidence From Turkey", Ege Akademik Bakış, 13 (2): 273-284.

- Kızılboğa, R. (2013). "İç Denetim Sisteminde Denetçilerin Bağımsızlık ve Tarafsızlı̆̆ının Önemi”, Marmara Üniversitesi Siyasal Bilimler Dergisi, 1(1): 107-119.

- Kurt, G. ve B. Akyüz. (2009). "Banka Denetim Komitelerinin Görev ve Sorumluluklarını Yerine Getirmedeki Etkinliklerine Yönelik Bir Araştırma”, MÖDAV Muhasebe Bilim Dünyas1 Dergisi, 11 (4), 233-258.

- Millstein, I. M. (1998). Corporate Governance: Improving Competitiveness And Access To Capital in Global Markets: A Report To The OECD, OECD Publishing.

- Oktay, S. (2003). Bağımsız Denetim Etkinliğinin Arttırılmasında, Denetim Hizmetinin Kalite Kontrolü ve Türkiye'deki Denetim Firmalarına Yönelik Bir Araştırma, İstanbul Üniversitesi Sosyal Bilimler Enstitüsü, Yayınlanmamış Doktora Tezi, İstanbul.

- Oktay, S. (2013). "Bağımsız Denetim Etkinliğinin Arttırılmasında, Denetim Hizmetinde Kalite Ve Kalite Kontrol: ABD Düzenlemeleri”, Maliye Finans Yazıları, 27 (100), 42-94.

- Otlu, F. (2001). "Muhasebe Mesleğinde Tarafsızlık Kavramı ve Tarafsız Bilgi Üretiminin Yeri ve Önemi”, Muhasebe ve Finansman Dergisi, 11: 87-94.

- Pehlivanlı, D. (2010). Modern İç Denetim Uygulamaları, İstanbul: Beta Yayınları.

- Rezaee, Z. (2002). Financial Statement Fraud: Prevention And Detection, USA: John Wiley \& Sons.

- Sönmez, A. ve A. Toksoy. (2011). "Kurumsal yönetim İlkelerinin Türkiye'deki Aile Şirketlerine Uygulanabilirliği”, Maliye ve Finans Yazıları Dergisi, 25 (92): 51-90.

- The Institute of Internal Auditors. (2008). Uluslararası İç Denetim Standartları (Mesleki Uygulama Çerçevesi ), İstanbul: Deloitte. 
- Türkiye Bankalar Birliği. (2006). Uluslararas1 Standartlar, http://www.Tbb.Org.Tr/Turkce/Arastirmalar/Uluslar_Arasi_Standartlar.Doc (Erişim tarihi: 11.10.2014).

- TÜSİAD. (2002). Kurumsal Yönetim En İyi Uygulama Kodu: Yönetim Kurulunun Yapısı ve İşleyişi, İstanbul: Yayın No. TÜSIAD-T/2002-12/336

- Uyar, S. (2004). "Kurumsal Şeffaflığın Sağlanmasında Kurumsal Yönetim (Corporate Governance) Anlayışının Önemi”, Mali Çözüm Dergisi, 66: 154-168.

- Uzay, Ş. (2004). "Türkiye' de Denetçi Bağımsızlığı”, MÖDAV The 1st Annual International Accounting Conferance Bildiri Kitab1, 3-5 November 2004, İstanbul, 435-485.

- Yılancı, M. (2003). "Denetim Komitesinin İç Denetimin Etkinliğini Sağlamadaki ve Hileleri Önlemedeki Rolü”, Muhasebe ve Denetime Bakış Dergisi, 3(7): 23-33.

- Wild, J. J. (1996). “The Audit Committee And Earnings Quality", Journal of Accounting, Auditing \& Finance, 11: 273-274. 